\title{
Multivalent interactions between an aromatic helical foldamer and a DNA G-quadruplex in the solid state
}

\author{
Pradeep K. Mandal, ${ }^{[a]}$ Benoit Baptiste, ${ }^{[a]}$ Béatrice Langlois d'Estaintot, ${ }^{\left[{ }^{[a]}\right.}$ Brice Kauffmann, ${ }^{[b]}$ and Ivan \\ $\mathrm{Huc}^{\star[a]}$
}

\begin{abstract}
Quinoline-based oligoamide foldamers have been identified as a potent class of G-quadruplex DNA ligands. Their helical structure is thought to target G-quadruplex loops or grooves and not G-tetrads. We report the cocrystal structure of anti-parallel hairpin dimeric DNA G-quadruplex $\left(\mathrm{G}_{4} \mathrm{~T}_{4} \mathrm{G}_{4}\right)_{2}$ with a helically folded tetraquinolinecarboxamide bearing cationic side chain consistent with this hypothesis. Multivalent foldamer-DNA interactions are observed that modify the packing of $\left(G_{4} T_{4} G_{4}\right)_{2}$ in the solid state.
\end{abstract}

Aromatic oligoamide foldamers ${ }^{[1]}$ may adopt stable folded conformations with predictable shapes such as helices, ${ }^{\left[{ }^{[2]}\right.}$ flat macrocycles,${ }^{[3]}$ sheets, ${ }^{[4]}$ or linear and zig-zag rods, ${ }^{[5]}$ the surface of which can be functionalized with proteinogenic side chains organized at precise positions in space. These decorated scaffolds are typically in the $1-5 \mathrm{kDa}$ range and constitute potent medium-size candidates - larger than small molecules and smaller than proteins - to recognize the surface of proteins or nucleic acids. For example, rod-like $\alpha$-helix mimetics have been developed as protein-protein interaction inhibitors; $;[$ anionic oligomers were shown to bind to and interfere with folding and aggregation of the islet amyloid polypeptide; ${ }^{[7]}$ pyrrole-imidazole oligomers are strong B-DNA minor groove binders; ${ }^{[8]}$ and some helical aromatic oligoamides have been shown to interact with the surface of human carbonic anhydrase $1 \mathrm{II}{ }^{[9]}$ In the context of these studies, accurate structural information is important but proves to be difficult to obtain. ${ }^{[8,9]}$ The results presented below thus constitute a rare example of structure elucidation of an aromatic foldamer-biopolymer assembly.

We have found that helical oligoamides of 8-amino-2quinolinecarboxylic acid bearing cationic side chains such as

[a] Dr. P. K. Mandal, Dr. B. Baptiste, Dr. B. Langlois d'Estaintot, Dr. I. Huc,

University of Bordeaux, CBMN (UMR 5248)

Institut Européen de Chemie et Biologie

2 rue Escarpit, 33600 Pessac, France

and

CNRS, CBMN (UMR 5248), France

and

Bordeaux Institut National Polytechnique, CBMN (UMR 5248),

France

E-mail: i.huc@iecb.u-bordeaux.fr

[b] Dr. B. Kauffmann

University of Bordeaux, IECB (UMS 3033)

Institut Européen de Chemie et Biologie

2 rue Escarpit, 33600 Pessac, France

and

CNRS, IECB (UMS 3033), France

and

INSERM, IECB (US001), France

Supporting information for this article is given via a link at the end of the document tetramer 1 (Fig. 1) bind to DNA G-quadruplexes in solution including the human telomeric G-quadruplex ( $\mathrm{H}$-telo) and quadruplex sequences of several gene promoters (e.g. c-kit1, ${ }^{[10]}$ $c-k i t 2,{ }^{[11]} c-m y c,{ }^{[12]} b c / 2,{ }^{[13]}$ and $k$-ras $\left.{ }^{[14]}\right) \cdot{ }^{[15]}$ In contrast, FRET melting assays showed that binding to duplex DNA is weaker. These findings were corroborated by the fact that directed DNA evolution studies against a related foldamer sequence twice as long as 1 yielded aptamers that all were G-quadruplex folds. ${ }^{[16]}$

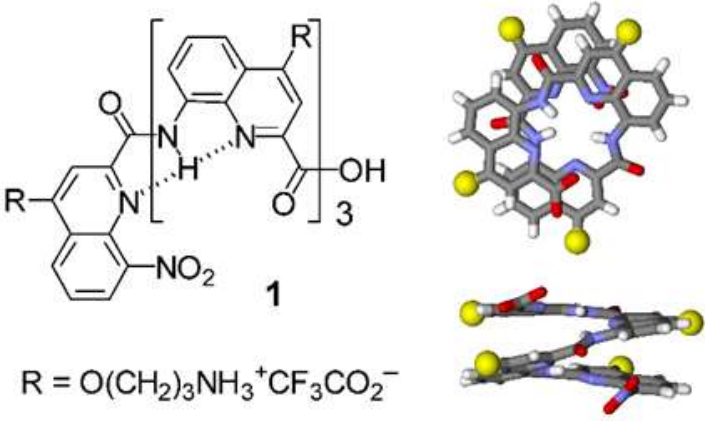

Figure 1. Formula and solid state folded structure of cationic tetramer 1.

Oligomers such as $\mathbf{1}$ adopt a very stable helical conformation in water due to the contribution of hydrophobic effects in intramolecular $\pi-\pi$ interactions. ${ }^{[17]}$ Since 1 possesses no stereogenic center, it exists as an equimolar mixture of righthanded and left-handed helices spanning over 1.5 turns. Foldamer-quadruplex interactions have been shown to be handedness-selective in the case of $\mathrm{H}$-telo ${ }^{[15 a]}$ and in the case of a DNA-aptamer. ${ }^{[16]}$ The non-flat shape of the helices hints at a foldamer binding mode to G-quadruplexes distinct from the classical stacking of flat cationic-aromatic ligands on top of the Gtetrads. ${ }^{[18]}$ Indeed, other ligands have been shown to bind to groove $^{[19]}$ or loop ${ }^{[20]}$ regions of G-quadruplexes. Helical and $C_{3}$ symmetrical aromatic objects have also been found to bind in the cavity of a three-way junction. ${ }^{[21]}$ In order to gain insights in the interactions between 1 and G-quadruplexes, we have sought for structural information and now report the cocrystal structure of 1 with the Oxytricha dimeric intermolecular G-quadruplex formed from two strands of d(GGGGTTTTGGGG) $)^{[22]}$ at a resolution of $2.48 \AA$. The structure (Fig. 2a) shows multivalent foldamerquadruplex interactions, suggesting a complex binding stoichiometry instead of a 1:1 well-defined complex. These interactions induce a different packing mode of the quadruplex and are consistent with our hypothesized absence of stacking onto G-tetrads.

Initial attempts focused on the crystallization of various cationic foldamers and macrocyles together with the $\mathrm{H}$-telo

For internal use, please do not delete. Submitted_Manuscript 
sequence for which interactions had been evidenced in solution. ${ }^{[15 c]}$ Crystallization using the standard hanging-drop vapour diffusion method from aqueous solutions only led to the formation of precipitates immediately after mixing the foldamers and DNA. No crystals grew from these samples. These precipitates were assigned to potential multivalent electrostatic interactions between the multianionic DNA and the multicationic cationic foldamers, which are both independently well soluble. Lowering concentration or adding monovalent or divalent metal ions did not prevent precipitation and did not help to obtain X-ray quality crystals.

The native Oxytricha sequence is well established to fold into a symmetric, bimolecular quadruplex in both crystalline and solution forms. ${ }^{[22,23]}$ We attempted co-crystallization of 1 with this sequence because it was known to crystallize more easily than the $\mathrm{H}$-telo quadruplex. It should be pointed that these crystallization attempts were made prior our recent development of a racemic DNA crystallographic approach in which both D- and L-DNA are mixed in equimolar amounts. ${ }^{[2]}$ Hence, only the Denantiomer i.e. D-d(GGGGTTTTGGGG) was used. As with $\mathrm{H}$-telo, the general outcome of mixing the foldamer and DNA was the immediate formation of a precipitate. However, in the case of $\mathbf{1}$, crystals eventually grew. Data collection and resolution led to the structure described below. Crystal data and refinement parameters (Table S1) and experimental details are presented in the supporting information.

The tetragonal unit cell dimensions observed for this crystal, i.e. $a=b=31.70 \AA$ and $c=97.37 \AA$ in space group $P 4_{1}$, is unique among the various structures of the Oxytricha sequence (see Table S2 for comparisons). Other structures reported in the $\mathrm{PDB}^{[25]}$ belong to the orthorhombic space group $\mathrm{P} 2{ }_{1}{ }_{2}{ }_{2}{ }_{1}$ and trigonal space group $\mathrm{P}_{2} 21$ for native, ligand-free, forms ${ }^{[22]}$ and orthorhombic space groups $\mathrm{P} 2{ }_{1} 2_{1} 2_{1}$ and $\mathrm{P} 2{ }_{1} 2_{1} 2$ for ligand-bound forms. ${ }^{[26]}$ The crystallographic asymmetric unit contains two DNA molecules assembled in a hairpin dimer G-quadruplex and one molecule of 1 (Fig. 2a). The G-quadruplex comprises two strands of d(GGGGTTTTGGGG) with a diagonal fold topology, in which the thymine loops $\mathrm{d}(\mathrm{TTTT}$ ) are lying diagonally across the top and bottom of the stack of guanine quartets, and the strands of each sequence are antiparallel to each other (Fig. 2a). This Gquadruplex fold is identical to the one found in the crystal structures of the Oxytricha native G-quadruplex ${ }^{[22 a, 22 c, 22 d]}$ and that found by NMR studies in $\mathrm{Na}^{+}$and $\mathrm{K}^{+}$environments. ${ }^{[23]}$ The electron density of $\mathbf{1}$ is well resolved and allows to assign the $\mathrm{N}$ terminal and C-terminal orientation of the helix, the position of the side-chains, as well as a left-handed helix sense (Fig. 2b). In solution, negative circular dichroism bands were observed near $400 \mathrm{~nm}$ in the absorption region of the quinoline chromophores of 1 upon adding the Oxytricha sequence (see Figures S1 and S2). Based on previous unambiguous assignments, ${ }^{[27]}$ this indicates that a left handed helix also prevails in solution.

The solid state structure is not that of a discrete complex but that of a co-crystal in which each foldamer interacts with several quadruplexes, and each quadruplex interacts with several foldamers, thus establishing an infinite network of molecules linked by multivalent interactions (Figure 3a). Figure 3b-d, compares Oxytricha DNA quadruplex packing in the absence and presence of ligands. Square-like arrangements of quadruplexes have been reported before ${ }^{[26 a]}$ but do not leave enough interstitial space to accommodate a foldamer. In contrast, multivalent DNA- foldamer interactions here promote increased quadruplexquadruplex distances, suggesting that they have guided crystal growth and packing. Cationic foldamer side chains were found to protrude towards DNA backbone loops and guanine grooves of adjacent G-quadruplexes. The limited resolution of our X-ray data prevented an accurate description of foldamer-DNA contact points, but these are presumably guided by ammoniumphosphate electrostatic interactions. These interactions occur at locations distinct from the phosphate-ammonium interactions observed between a spermine molecule and the native Oxytricha quadruplex sequence in the solid state (PDB \# 3UEI). ${ }^{266]}$ In the latter, two salt bridges (phosphate-oxygen ammonium-nitrogen distance $<3.3 \AA$ ) are observed between spermine ammonium groups and the last two ( $3^{\prime}$ end) dG phosphate groups of a d(GGGGTTTTGGGG) strand. In the foldamer-quadruplex cocrystal, probable ammonium-phosphate interactions involve the dT in the loops (side chain 2 in Fig. 3a). Noteworthy is the presence of spermine in the crystallization medium, and its absence from the electron density map, of the foldamerquadruplex co-crystal.
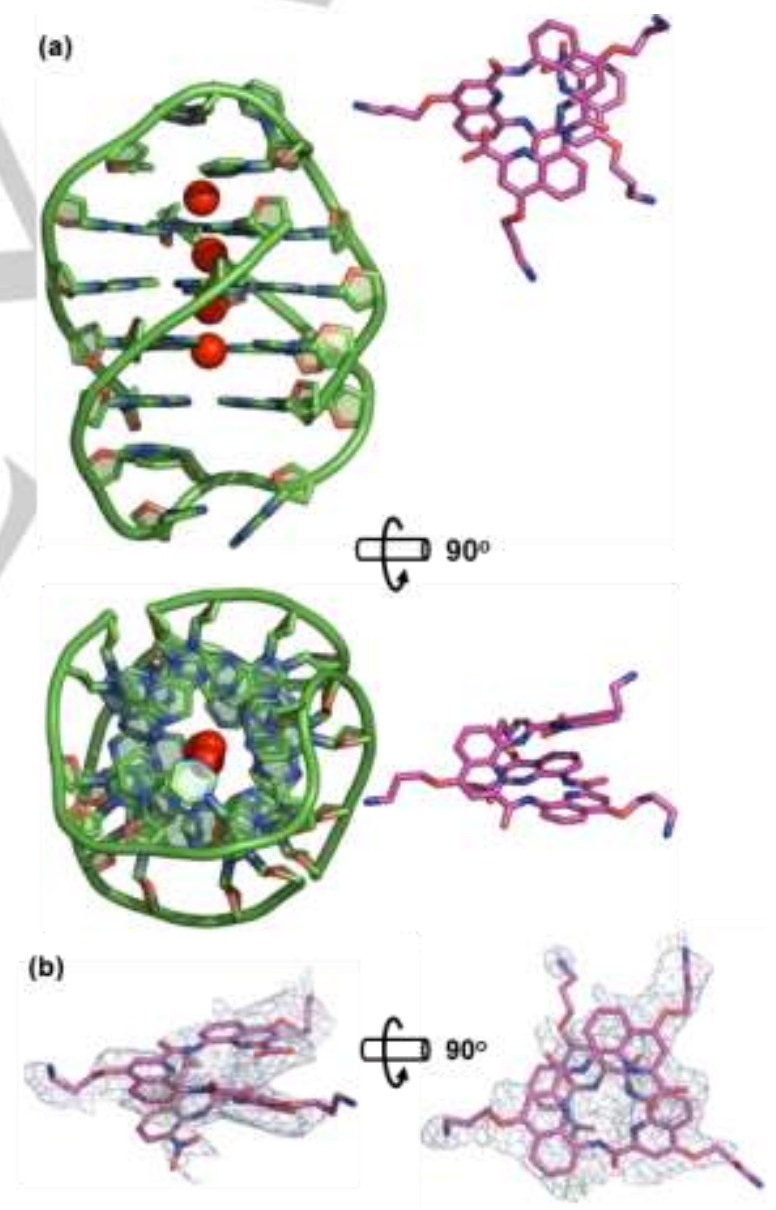

Figure 2. (a) Asymmetric unit consisting of d(GGGGTTTTGGGG) $)_{2}$ (green) and 1 (magenta). $\mathrm{K}^{+}$ions shown as red spheres. (b) Sigma-weighted $2 F_{\mathrm{o}}-F_{\mathrm{c}}$ (grey mesh, contoured at $1 \sigma$ level) and $F_{0}-F_{c}$ (green mesh, contoured at $3 \sigma$ level) electron density map superimposed to 1 . 

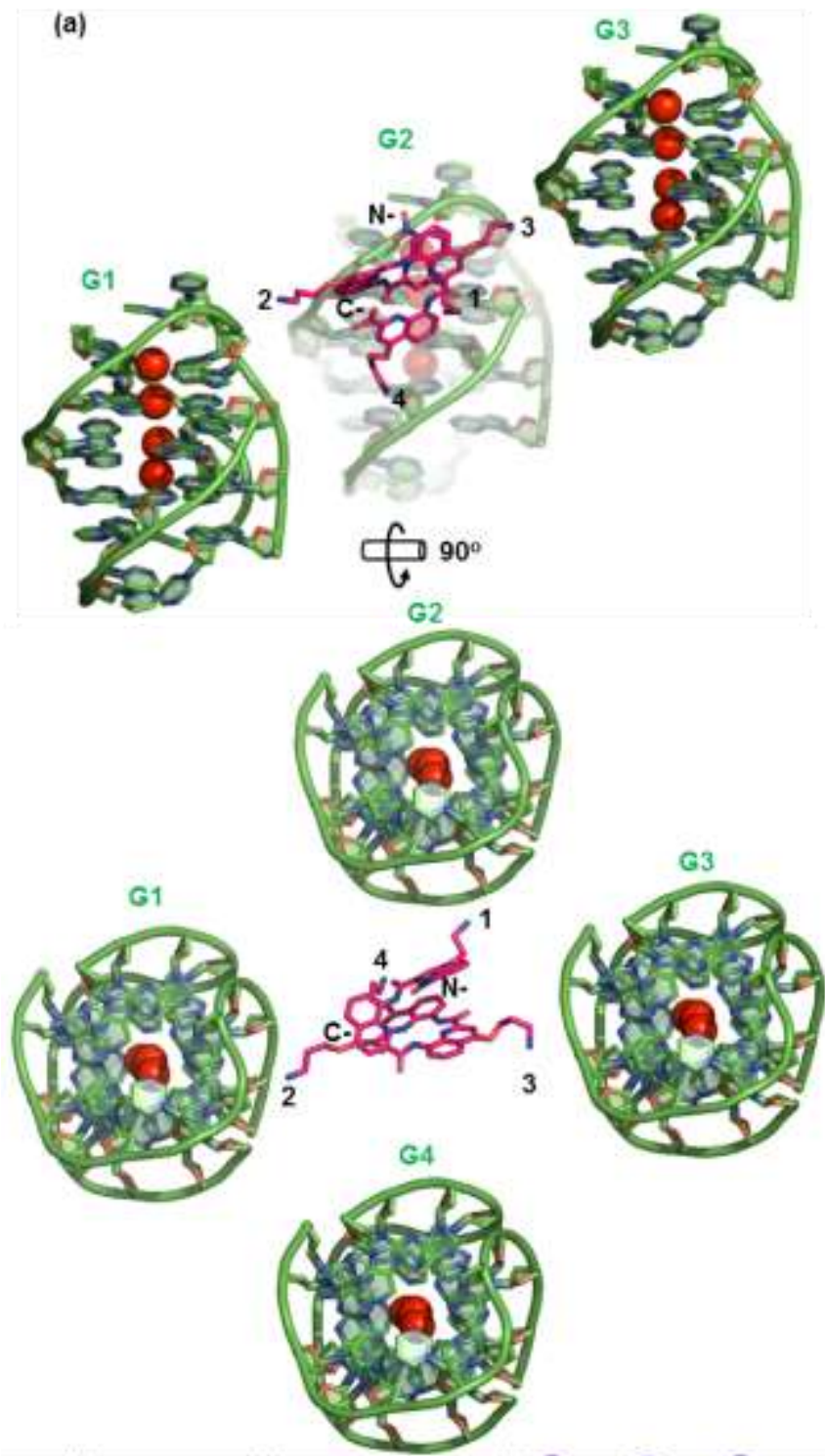

(b)

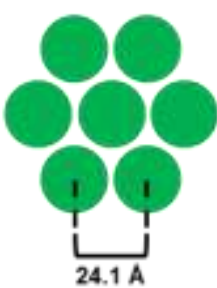

(c)

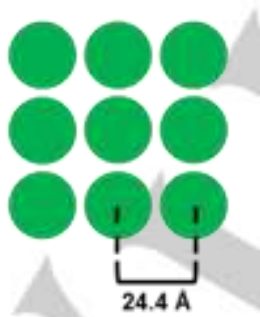

(d)
Figure 3. (a) Packing arrangement of 1 (magenta) surrounded by symmetry related d(GGGGTTTTGGGG) 2 G-quadruplexes (green, numbered G1-G4). The cationic side chains are numbered 1-4. (b-d) Packing arrangement of d(GGGGTTTTGGGG) 2 (green circles, viewed down the quadruplex axis) in: (b) native, ligand-free form; ${ }^{[22 c]}$ (c) flat aromatic ligand-bound form; ${ }^{[26 a]}$ and (d) with bound 1 (magenta). Quadruplex-quadruplex distances were calculated using vertical alignment of consecutive $\mathrm{K}^{+}$ions within the central core of these $\mathrm{G}$ quadruplexes.

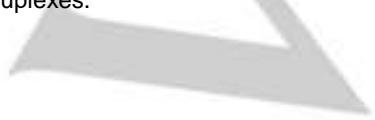

The contacts between the foldamer and the quadruplex groove and loops are consistent with our assumption that an aromatic helix is ill suited to stack at the top of G-tetrads as many flat ligands do. The role of "molecular glue" that 1 plays in Gquadruplex packing is reminiscent of a recently described protein assembly driven by calixarene molecules. ${ }^{[28]}$

In conclusion, we have brought the first piece of structural information about interactions between aromatic amide foldamers and G-quadruplex DNA. The structure shows multivalent foldamer-DNA electrostatic interactions that guide DNA packing, and reveal a preferred left-handed screw sense of the foldamer helix upon interacting with the Oxytricha sequence. The structure validates our previous hypothesis of an absence of stacking of the foldamer onto G-tetrads. A well-defined DNA-foldamer complex, if it exists, is not stable enough to overcome the observed interactions. We anticipate that more selective interactions that would serve structure-based rational foldamer design may exist between G-quadruplex DNA aptamers and the cationic foldamer that they have been selected to bind. ${ }^{[16]}$ Efforts to grow crystals of this complex are currently under way.

\section{Experimental Section}

Experimental details are given in the Supporting Information. Final coordinates and structure factors have been deposited in the PDB ${ }^{[25]}$ with entry code $5 \mathrm{HIX}$.

\section{Acknowledgements}

We thank the European Synchrotron Radiation Facility for providing access to data collection facilities, and are grateful to the beamline staff of French beam line for Investigation of Proteins (FIP) for assistance. This work was supported by the European Union's Seventh Framework Program through the European Research Council (grant agreement no. ERC-2012AdG-320892, postdoctoral fellowship to P.K.M.).

Keywords: DNA structures • foldamers • G-quadruplex • foldamer-based DNA ligands $\bullet$ foldamer-DNA interactions

[1] For reviews: I. Huc, Eur. J. Org. Chem. 2004, 1, 17-29; D.-W. Zhang, X Zhao, J.-L. Hou, Z.-T. Li, Chem. Rev. 2012, 112, 5271-5316.

[2] J. Zhu, R. D. Parra, H. Zeng, E. Skrzypczak-Jankum, X. C. Zeng, B. Gong, J. Am. Chem. Soc. 2000, 122, 4219-4220; H. Jiang, J-M, Léger, I. Huc, J. Am. Chem. Soc. 2003, 125, 3448-3449.

[3] S. Ferguson, K. Yamato, R. Liu, L. He, X. C. Zeng, B. Gong, Angew. Chem. Int. Ed. 2009, 48, 3150-3154; Angew. Chem. 2009, 121, 31963200; H. Fu, Y. Liu, H. Zeng, Chem. Commun. 2013, 49, 4127-4144.

[4] L. Sebaoun, V. Maurizot, T. Granier, B. Kauffmann, I. Huc, J. Am. Chem. Soc. 2014, 136, 2168-2174.

[5] Y. Hamuro, S. J. Geib, A. D. Hamilton, J. Am. Chem. Soc. 1996, 118 7529-7541; J. T. Ernst, J. Becerril, H. S. Park, H. Yin, A. D. Hamilton, Angew. Chem. Int. Ed. 2003, 42, 535-539; Angew. Chem. 2003, 115, 553-557; E. Kolomiets, V. Berl, I. Odriozola, A.-M. Stadler, N. Kyritsakas J.-M. Lehn, Chem. Commun. 2003, 7, 2868-2869; Z.-Q. Wu, X.-K. Jiang, S.-Z. Zhu, Z.-T. Li, Org. Lett. 2004, 6, 229-232.

[6] B. P. Orner, J. T. Ernst, A. D. Hamilton, J. Am. Chem. Soc. 2001, 123 5382-5383; H. Yin, G. Lee, K. A. Sedey, O. Kutzki, H. S. Park, B. P. Orner, J. T. Ernst, H.-G. Wang, S. M. Sebti, A. D. Hamilton, J. Am. Chem. 
Soc. 2005, 127, 10191-10196; H. Yin, G. Lee, H. S. Park, G. A. Payne J. M. Rodriguez, S. M. Sebti, A. D. Hamilton, Angew. Chem. Int. Ed. 2005 44, 2704-2707; Angew. Chem. 2005, 117, 2764-2767; J. M. Rodriguez, A. D. Hamilton, Angew. Chem. Int. Ed. 2007, 46, 8614-8617; Angew. Chem. 2007, 119, 8768-8771; J. P. Plante, T. Burnley, B. Malkova, M. E. Webb, S. L. Warriner, T. A. Edwards, A. J. Wilson, Chem. Commun 2009, 5091-5093; J. M. Rodriguez, N. T. Ross, W. P. Katt, D. Dhar, G. Lee, A. D. Hamilton, ChemMedChem. 2009, 4, 649-656; W. E. Martucci, J. M. Rodriguez, M. A. Vargo, M. Marr, A. D. Hamilton, K. S. Anderson, Med. Chem. Commun., 2013, 4, 1247-1256; V. Azzarito, J. A. Miles, J. Fisher, T. A. Edwards, S. L. Warriner, A. J. Wilson, Chem. Sci. 2015, 6, 2434-2443.

[7] J. A. Hebda, I. Saraogi, M. Magzoub, A. D. Hamilton, A. D. Miranker, Chem. Biol. 2009, 16, 943-950; I. Saraogi, J. A. Hebda, J. Becerril, L. A Estroff, A. D. Miranker, A. D. Hamilton, Angew. Chem. Int. Ed. 2010, 49 736-739; Angew. Chem. 2010, 122, 748-751; S. Kumar, A. D. Miranker, Chem. Commun. 2013, 49, 4749-4751; S. Kumar, D. E. Schlamadinger, M. A. Brown, J. M. Dunn, B. Mercado, J. A. Hebda, I. Saraogi, E. Rhoades, A. D. Hamilton, A. D. Miranker, Chem. Biol. 2015, 22, 369378; S. Kumar, M. Birol, D. E. Schlamadinger, S. P. Wojcik, E. Rhoades, A. D. Miranker, Nat. Commun. 2016, 7, 11412 doi: 10.1038/ncomms11412; S. Kumar, M. A. Brown, A. Nath, A. D. Miranker, Chem. Biol. 2014, 21, 775-781; S. Kumar, M. Birol, A. D. Miranker, Chem. Comm. 2016, 52, 6391-6394.

[8] P. B. Dervan, B. S. Edelson, Curr. Opin. Struct. Biol. 2003, 13, 284-299; T. Bando, H. Sugiyama, Acc. Chem. Res. 2006, 39, 935-944; R. D. Taylor, Y. Kawamoto, K. Hashiya, T. Bando, H. Sugiyama, Chem. Asian J. 2014, 9, 2527-2533.

[9] J. Buratto, C. Colombo, M. Stupfel, S. J. Dawson, C. Dolain, B. Langlois d'Estaintot, L. Fischer, T. Granier, M. Laguerre, B. Gallois, I. Huc, Angew. Chem. Int. Ed. 2014, 53, 883-887; Angew. Chem. 2014, 126, 902-906; M. Jewginski, L. Fischer, C. Colombo, I. Huc, C. D. Mackereth, ChemBioChem. 2016, 17, 727-736.

[10] A. T. Phan, V. Kuryavyi, S. Burge, S. Neidle, D. J. Patel, J. Am. Chem. Soc. 2007, 129, 4386-4392.

[11] H. Fernando, A. P. Reszka, J. Hupert, S. Ladame, S. Rankin, A. R. Venkitaraman, S. Neidle, S. Balasubramanian, Biochemistry 2006, 45, 7854-7860.

[12] A. Rangan, O. Y. Fedoroff, L. H. Hurley, J. Biol. Chem. 2001, 276, 46404646; J. Seenisamy, E. M. Rezler, T. J. Powell, D. Tye, V. Gokhale, C. S. Joshi, A. Siddiqui-Jain, L. H. Hurley, J. Am. Chem. Soc. 2004, 126, 8702-8709.

[13] S. Cogoi, M. Paramasivam, B. Spolaore, L. E. Xodo, Nucleic Acids Res. 2008, 36, 3765-3780.

[14] J. Dai, T. S. Dexheimer, D. Chen, M. Carver, A. Ambrus, R. A. Jones, D. Yang, J. Am. Chem. Soc. 2006, 128, 1096-1098; P. Agrawal, C. Lin, R. I. Mathad, M. Carver, D. Yang, J. Am. Chem. Soc. 2014, 136, 1750-1753.

[15] (a) P. S. Shirude, E. R. Gillies, S. Ladame, F. Godde, K. Shin-ya, I. Huc, S. Balasubramanian, J. Am. Chem. Soc. 2007, 129, 11890-11891; (b) P. V. Jena, P. S. Shirude, B. Okumus, K. Laxmi-Reddy, F. Godde, I. Huc, S. Balasubramanian, T. Ha, J. Am. Chem. Soc. 2009, 131, 12522 12523; (c) S. Müller, K. Laxmi-Reddy, P. V. Jena, B. Baptiste, Z. Dong F. Godde, T. Ha, R. Rodriguez, S. Balasubramanian, I. Huc, ChemBioChem 2014, 15, 2563-2570.

[16] L. Delauriere, Z. Dong, K. Laxmi-Reddy, F. Godde, J.-J. Toulme, I. Huc, Angew. Chem. Int. Ed. 2012, 51, 473-477; Angew. Chem. 2012, 124 488-492.

[17] T. Qi, V. Maurizot, H. Noguchi, T. Charoenraks, B. Kauffmann, M. Takafuji, H. Ihara, I. Huc, Chem. Commun. 2012, 48, 6337-6339.

[18] D. Monchaud, M.-P. Teulade-Fichou, Org. Biomol. Chem. 2008, 6, 627636; R. Rodriguez, S. Muller, J. A. Yeoman, C. Trentesaux, J.-F. Riou, S. Balasubramanian, J. Am. Chem. Soc. 2008, 130, 15758-15759; A De Cian, E. DeLemos, J.-L, Mergny, M.-P. Teulade-Fichou, D. Monchaud, J. Am. Chem. Soc. 2008, 129, 1856-1857; S. Sparapani, S. M. Haider, F. Doria, M. Gunaratnam, S. Neidle, J. Am. Chem. Soc. 2010 132, 12263-12272; A. Laguerre, N. Desbois, L. Stefan, P. Richard, C. P. Gros, D. Monchaud, ChemMedChem. 2014, 9, 2035-2039; M. Bejugam,
M. Gunaratnam, S. Muller, D. A. Sanders, S. Sewitz, J. A. Fletcher, S. Neidle, S. Balasubramanian, ACS Med. Chem. Lett. 2010, 1, 306-310; W. J. Chung, B. Heddi, F. Hamon, M.-P. Teulade-Fichou, A. T. Phan, Angew. Chem. Int. Ed. 2014, 53, 999-1002; Angew. Chem. 2014, 53 1017-1020.

[19] L. Martino, A. Virno, B. Pagano, A. Virgilio, S. Di Micco, A. Galeone, C Giancola, G. Bifulco, L. Mayol, A. Randazzo, J. Am. Chem. Soc. 2007 129, 16048-16056; K.-i. Shinohara, Y. Sannohe, S. Kaieda, K. Tanaka H. Osuga, H. Tahara, Y. Xu, T. Kawase, T. Bando, H. Sugiyama, J. Am. Chem. Soc. 2010, 132, 3778-3782; S. Cosconati, L. Marinelli, R. Trotta A. Virno, S. De Tito, R. Romagnoli, B. Pagano, V. Limongelli, C. Giancola, P.G. Baraldi, L. Mayol, E. Novellino, A. Randazzo, J. Am. Chem. Soc. 2010, 132, 6425-6433; F. Hamon, E. Largy, A. Guedin-Beaurepaire, M. Rouchon-Dagois, A. Sidibe, D. Monchaud, J.-L. Mergny, J.-F. Riou, C.H. Nguyen, M.-P. Teulade-Fichou, Angew. Chem. Int. Ed. 2011, 50, 8745-8749; Angew. Chem. 2011, 123, 8904-8908.

[20] S. Burge, G. N. Parkinson, P. Hazel, A. K. Todd, S. Neidle, Nucleic Acids Res. 2006, 34, 5402-5415; T. Kimura, K. Kawai, M. Fujitsuka, T. Majima, Tetrahedron 2007, 63, 3585-3590.

[21] D. R. Boer, J. M. C. A. Kerckhoffs, Y. Parajo, M. Pascu, I. Uson, P. Lincoln, M. J. Hannon, M. Coll, Angew. Chem. Int. Ed. 2010, 49, 23362339; Angew. Chem. 2010, 122, 2386-2389; S. A. Barros, D. M. Chenoweth, Angew. Chem. Int. Ed. 2014, 53, 13746-13750; Angew. Chem. 2014, 126, 13966-13970.

[22] (a) C. H. Kang, X. Zhang, R. Ratliff, R. Moyzis, A. Rich, Nature 1992, 356, 126-131; (b) M. P. Horvath, S. C. Schultz, J. Mol. Biol. 2002, 310, 367377; (c) S. Haider, G. N. Parkinson, S. Neidle, J. Mol. Biol. 2002, 320, 189-200; (d) M. L. Gill, S. A. Strobel, J. P. Loria, Nucleic Acids Res. 2006, $34,4506-4514$

[23] F. W. Smith, J. Feigon, Nature 1992, 356, 164-168; P. Schultze, F. W. Smith, J. Feigon, Structure 1994, 2, 221-233; P. Schultze, N. V. Hud, F W. Smith, J. Feigon, Nucleic Acids Res. 1999, 27, 3018-3028.

[24] P. K. Mandal, G. W. Collie, B. Kauffmann, I. Huc, Angew. Chem. Int. Ed. 2014, 53, 14424-14427; Angew. Chem. 2014, 126, 14652-14655; P. K. Mandal, G. W. Collie, S. C. Srivastava, B. Kauffmann, I. Huc, Nucleic Acids Res. 2016, 44, 5936-5943.

[25] H. M. Berman, J. Westbrook, Z. Feng, G. Gilliland, T. N. Bhat, H. Weissig I. N. Shindyalov, P. E. Bourne, Nucleic Acids. Res. 2000, 28, 235-242.

[26] (a) S. Haider, G. N. Parkinson, S. Neidle, J. Mol. Biol. 2003, 326, 117125; (b) N. H. Campbell, M. Patel, A. B. Tofa, R. Ghosh, G. N. Parkinson, S. Neidle, Biochemistry 2009, 48, 1675-1680; (c) N. H. Campbell, D. L. Smith, A. P. Reszka, S. Neidle, D. O'Hagan, Org. Biomol. Chem. 2011, 9, 1328-1331.

[27] C. Dolain, H. Jiang, J.-M. Léger, P. Guionneau, I. Huc, J. Am. Chem. Soc. 2005, 127, 12943-12951; A. M. Kendhale, L. Poniman, Z. Dong, K. Laxmi-Reddy, B. Kauffmann, Y. Ferrand, I. Huc, J. Org. Chem. 2011, 76, 195-200.

[28] For examples: R. E. McGovern, A. A. McCarthy, P. B. Crowley, Chem. Commun. 2014, 50, 10412-10415; R. E. McGovern, H. Fernandes, A. R. Khan, N. P. Power, P. B. Crowley, Nat Chem. 2012, 4, 527-533. 
Entry for the Table of Contents (Please choose one layout)

Layout 1:

\section{COMMUNICATION}

Multiple arylamide foldamer-DNA contacts. A cationic aromatic helical foldamer and a G-quadruplex DNA form a solid state assembly stabilized by multivalent interactions.

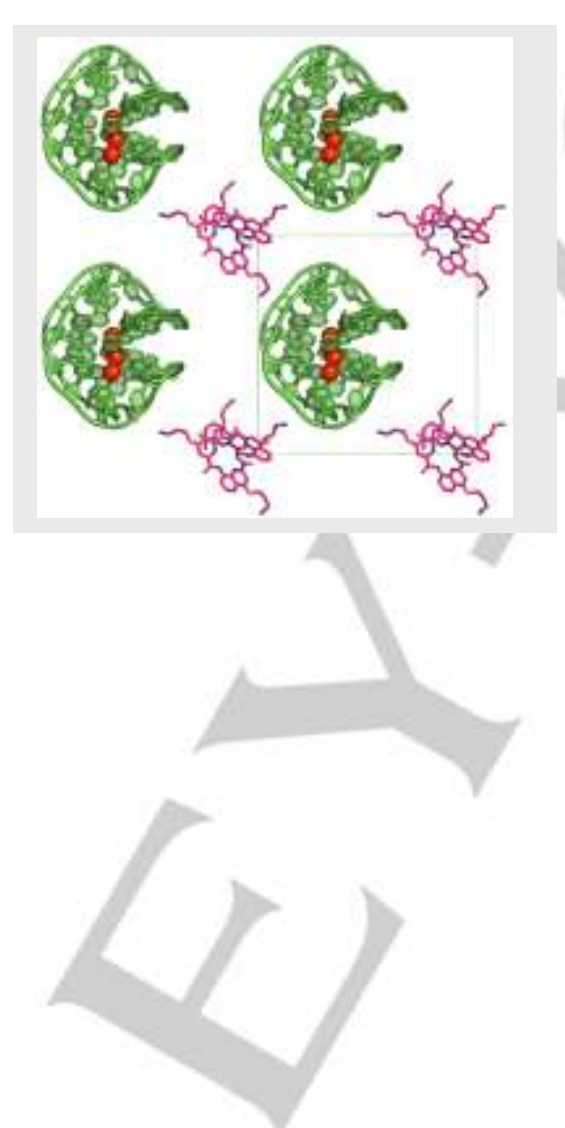

P. K. Mandal, B. Baptiste, B. Langlois d'Estaintot, B. Kauffmann, I. Huc*

Page No. - Page No.

Multivalent interactions between an aromatic helical foldamer and a DNA G-quadruplex in the solid state 